\title{
ТЕНДЕНЦИИ РАЗВИТИЯ ЛЕСОПРОМЫШЛЕННОГО КОМПЛЕКСА ИРКУТСКОЙ ОБЛАСТИ
}

\author{
С. В. Костылева \\ Байкальский государственный университет, г. Иркутск, Российская Федерация
}

Информация о статье

Дата поступления

22 июня 2017 г.

Дата принятия к печати

21 мая 2018 г.

Дата онлайн-размещения

8 июня 2018 г.

\section{Ключевые слова}

Лесопромышленный

комплекс; тенденции развития; лесозаготовка; обработка

древесины; целлюлозно-

бумажные изделия;

инвестиционные проекты

\section{Аннотация}

Лесная промышленность вносит существенный вклад в экономику Иркутской области. Ее отрасли представлены заготовкой древесины, деревопереработкой (производство пиломатериалов, древесно-волокнистых, древесно-стружечных плит, фанеры), целлюлозно-бумажной промышленностью. Наличие на территории Иркутской области крупнейших в России лесных ресурсов послужило базой для создания в регионе высокоразвитого лесопромышленного комплекса, продукция которого потребляется как внутри страны, так и за рубежом. В данной статье был проведен анализ тенденций, сложившихся в сфере лесопромышленного комплекса за последние семь лет. Были рассмотрены статистические данные об основных показателях деятельности, а также финансовые результаты предприятий лесопромышленного комплекса Иркутской области. В качестве инструментария для исследования был использован сравнительный анализ. Сделан анализ налоговых поступлений в консолидированный бюджет Иркутской области от сфер деятельности лесопромышленных предприятий. Рассмотрены основные характеристики лесосырьевого потенциала Иркутской области, а также особенности функционирования лесозаготовительной промышленности региона. В целях усиления механизмов привлечения инвестиций в лесопромышленный комплекс предложен ряд мероприятий. Сорормулированы выводы о перспективах развития лесопромышленного комплекса Иркутской области.

\section{TRENDS IN THE DEVELOPMENT OF THE TIMBER PROCESSING COMPLEX OF IRKUTSK OBLAST}

\author{
Svetlana V. Kostyleva \\ Baikal State University, Irkutsk, the Russian Federation
}

\section{Article info}

Received

June 22, 2017

Accepted

May 21, 2018

Available online

June 8, 2018

\section{Keywords}

Timber processing complex; development trends; logging; wood processing; pulp and paper products; investment projects

\begin{abstract}
The timber industry makes a significant contribution to the economy of Irkutsk Oblast, its branches are represented by: logging, wood processing (production of sawn timber, fibreboard, chipboard, plywood), pulp and paper industry. Irkutsk Oblast has the largest forest resources in Russia. They are a base for the creation of a highly developed timber-processing complex in the region; its products are consumed both domestically and abroad. This article is dedicated to the analysis of the trends in the timber processing industry over the past seven years. The author examined statistical data of the basic performance indicators, as well as the financial results of the enterprises of the timber-processing complex of Irkutsk Oblast. Comparative analysis was used as a research tool. The author made the analysis of tax revenues into the consolidated budget of the Irkutsk region derived from the spheres of activity of timber enterprises. She also examined the main characteristics of the forest resource potential of Irkutsk Oblast, as well as the features of the forestry industry of the region. In order to strengthen mechanisms for attracting investments in the timber processing industry, the author proposes a number of measures and draws conclusions about the prospects for the development of the timber industry complex in Irkutsk Oblast.
\end{abstract}


В ходе научно-технического прогресса сорормировались новые производства, которые постепенно складывались в отдельные отрасли: деревообрабатывающую, целлюлозно-бумажную и лесохимическую. Совокупность этих отраслей представляет собой лесопромышленный комплекс.

Как показывает отечественный и зарубежный опыт, наиболее эфффективные показатели в области экономики в сфере лесопромышленного комплекса достигаются там, где сформирован механизм глубокой переработки древесины при использовании лесных ресурсов.

Только при комплексной оценке эффрективности производства в лесной промышленности в целях перспективного развития лесной отрасли возможно добиться наилучших экономических результатов. Для достижения поставленных целей А. П. Петров и Ф. Н. Морозов выделили три направления эффеекта: экономический, социальный и экологический [1]. На рис. 1 представлены три направления эффрективности производства в лесной промышленности.

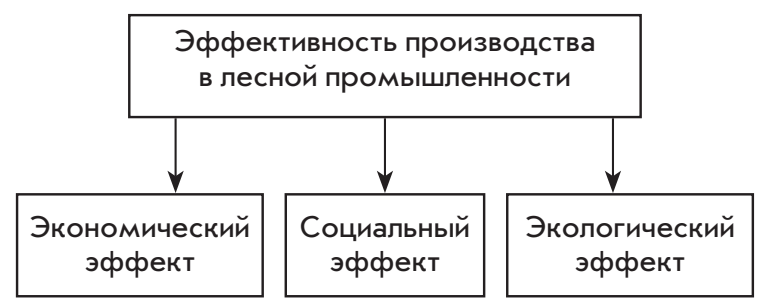

Рис. 1. Направления эффективности производства в лесной промышленности

Экономический эффрект достигается путем соотношения оценки результатов производственной деятельности и показателя привлекаемых к обороту производственных ресурсов. Социальный эффект при использовании лесных ресурсов предусматривается в расширении линейки продукции из древесных ресурсов, в том числе из древесных отходов, которая поступает к потребителям. Эффрект в области экологии может быть достигнут благодаря мероприятиям, направленным на охрану и защиту окружающей среды как в регионе, так и в государстве в целом. Итоги совокупности показателей экономического, социального и экологического эффекта равны оценке результатов деятельности предприятий в лесной промышленности [там же, с. 10].

Рассмотрим основные характеристики лесосырьевого потенциала Иркутской области, а также особенности функционирования лесозаготовительной промышленности региона.
На территории Иркутской области сосредоточено 12 \% запасов древесины спелых лесов страны, а доля особо ценных хвойных пород, таких как сосна и кедр, значительна даже в масштабах планеты. Покрытая лесом территория достигает порядка 64,3 млн га, из них 43 \% спелых и перестойных лесов. От общей площади сосновых лесов в России леса Иркутской области составляют 13,5%. Это очень значительные показатели. Наибольшие массивы сосновых лесов находятся в бассейне реки Ангары, в южной части Среднесибирского плоскогорья. На севере Иркутской области преобладают мягколиственные породы деревьев. В силу того что в северной части Иркутской области инфраструктура развита слабо, продукция из лиственных пород востребована не в полном объеме [2].

С целью повышения инвестиционной привлекательности лесопромышленного комплекса Иркутской области одним из приоритетных направлений деятельности должно стать создание условий для развития транспортной инфраструктуры - строительство лесовозных дорог и хорошее их обслуживание, что подчеркнули Г. В. Давыдова и А. И. Бирюкова $[3 ; 4$, с. 15].

В гористой местности расположены кедровые леса, которые составляют $18 \%$ от общей площади кедровых лесов Российской Федерации. Кедр представляет собой особо ценную породу, поэтому заготовка древесины в кедровых лесах не проводится. Значительные запасы спелой древесины сосредоточены в Усть-Илимском, Чунском, Киренском, Братском, Усть-Кутском, Нижнеилимском и Казачинско-Ленском районах области. Самый бедный древесиной район - Нукутский, лесистость там составляет $24 \%$. Самый богатый - Усть-Кутский район (95\%). Активно в регионе развивается лесная промышленность. На рис. 2 и 3 представлены показатели объемов заготовки древесины, пиломатериалов, целлюлозы, картона за последние семь лет ${ }^{1}$. Наблюдается рост всей линейки продукции лесной промышленности, за исключением производства картона, которое уменьшилось на 17 \% за исследуемый период.

1 Лесной комплекс Иркутской области, 2010 : стат. сб. / Иркутскстат. Иркутск, 2011. 48 с. ; Лесной комплекс Иркутской области, 2011 : стат. сб. / Иркутскстат. Иркутск, 2012. 87 с. ; Лесной комплекс Иркутской области, 2012 : стат. сб. / Иркутскстат. Иркутск, 2013. 93 с. ; Лесной комплекс Иркутской области, 2014 : стат. сб. / Иркутскстат. Иркутск, 2015. 89 с. ; Лесной комплекс Иркутской области, 2015 : стат. сб. / Иркутскстат. Иркутск, 2016. 92 с. 


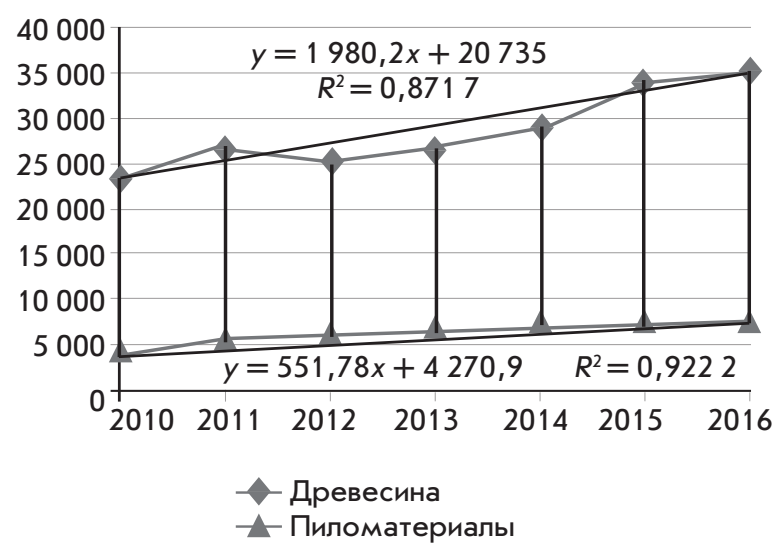

Рис. 2. Объемы заготовки древесины и пиломатериалов за период 2010-2016 гr., тыс. $\mathrm{M}^{3}$

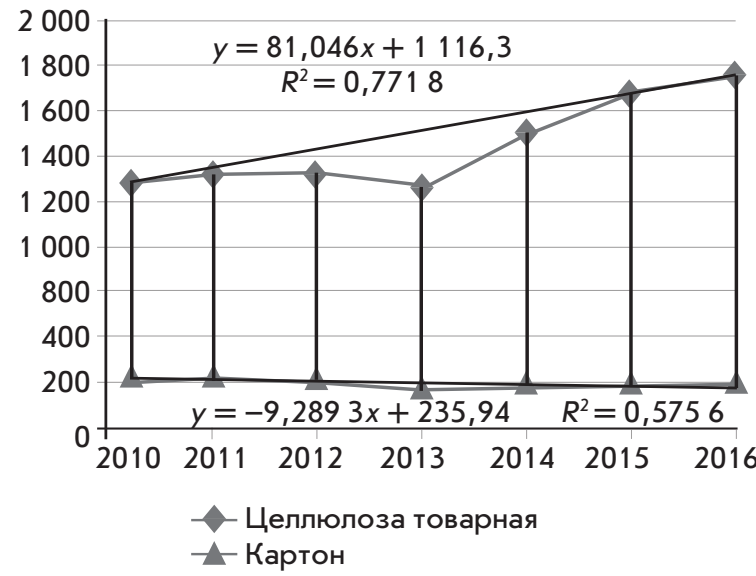

Рис. 3. Объемы производства товарной целлюлозы и картона за период 2010-2016 гг., тыс. т

Следовательно, основной тенденцией развития лесной промышленности региона за исследуемый период является рост производства основных видов лесной продукции. Особенности развития можно сорормулировать так:

- темпы роста переработки древесины опережают темпы ее заготовки, что свидетельствует об увеличении глубины переработки;

- регион осваивает производство новых видов лесопродукции и снижает производство продукции, не пользующейся спросом;

- активизируется работа предприятий по более активному использованию в качестве сырья мягколиственных пород и древесных отходов для производства продукции (пеллеты, брикеты, древесный уголь, топливные гранулы).

Иркутская область активно поставляет древесину и целлюлозно-бумажные изделия в зарубежные страны. Так, в 2016 г. экспорт составил 2 160,6 млн дол. Объем экспорта целлюлозно-бумажной продукции с 2014 по 2016 г. возрос на 234 млн р., что составляет 17 \% увеличения (рис. 4). Основными потре- бителями древесины и целлюлозно-бумажных изделий Иркутской области являются такие страны, как Китай, Япония, Узбекистан, Египет и Республика Корея.

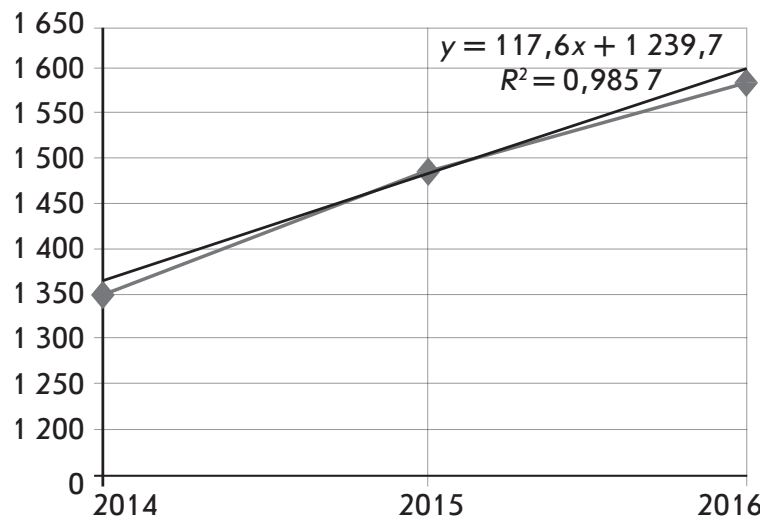

Рис. 4. Объем экспорта целлюлозы древесной, бумаги и картона за 2014-2016 гг., тыс. т

В товарной структуре экспортаИркутской области древесина и целлюлозно-бумажные изделия составляют около 40 \%. На Иркутскую область приходится 25 \% от объема экспорта древесины и целлюлозно-бумажных изделий Российской Федерации. Ввоз на территорию Иркутской области импортной древесины и целлюлозно-бумажных изделий производится в незначительных объемах из Австрии, Китая и Румынии [5]. Исходя из данных, представленных на рис. 4 и 5, можно выявить следующую тенденцию внешнеэкономической деятельности: происходит совершенствование структуры экспорта за счет сокращения объемов продаж круглого леса и роста экспорта продукции с высокой добавленной стоимостью².

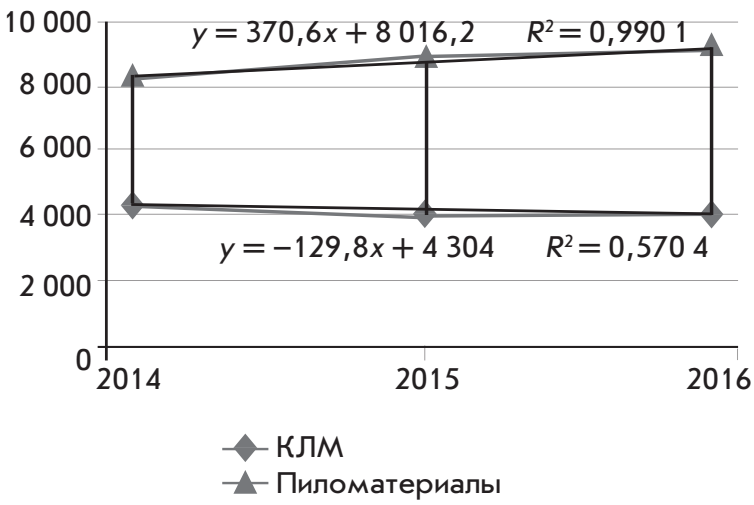

Рис. 5. Объем экспорта лесопромышленной продукции за период 2014-2016 гг., тыс. м $^{3}$

2 Лесной комплекс Иркутской области, 2010 : стат. сб. ; Лесной комплекс Иркутской области, 2011 : стат. сб. ; Лесной комплекс Иркутской области, 2012 : стат. сб. ; Лесной комплекс Иркутской области, 2014 : стат. сб. ; Лесной комплекс Иркутской области, 2015 : стат. сб. 
Развитие лесопромышленного комплекса напрямую зависит от кадрового потенциала отрасли. Среднемесячная заработная плата работников ЛПК за 2016 г. составила 34688,7 р. (+14,1 \% к 2015 г.). Темп роста заработной платы в лесопромышленном комплексе Иркутской области ежегодно превышает уровень иноляции и в последние три года превысил темп роста среднемесячной зарплаты по области. Если в 2010 г. среднеобластная заработная плата была выше заработной платы в лесопромышленном комплексе почти на $30 \%$, то к 2016 г. зарплата в ЛПК приблизилась к областному значению (рис. 6) ${ }^{3}$.

Среднесписочная численность работников лесного комплекса на 1 января 2017 г. составила 34,6 тыс. чел. (табл. 1) 4 . С 2010 по 2016 г. количество занятых в производствах заметно сократилось. Так, в 2016 г. среднегодовая численность работников снизилась почти на 7 тыс. чел. по сравне-

3 Лесной комплекс Иркутской области. 2010 : стат. сб. ; Лесной комплекс Иркутской области. 2011 : стат. сб. ; Лесной комплекс Иркутской области. 2012 : стат. сб. ; Лесной комплекс Иркутской области. 2014 : стат. сб. ; Лесной комплекс Иркутской области. 2015 : стат. сб.

4 Тамже. нию с 2010 г. Вместе с тем по сравнению с 2015 г. в 2016 г. численность работников увеличилась на $8,8 \%$.

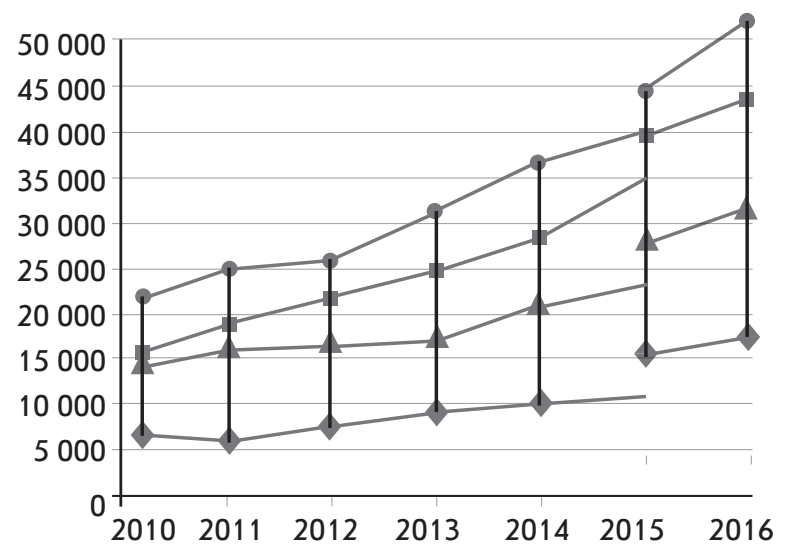

-— Производство целлюлозы, древесной массы, бумаги, картона и изделий из них

- - Лесозаготовки

__ Обработка древесины и производство изделий из дерева

- Производство мебели
Рис. 6. Среднемесячная заработная плата работников по отраслям лесопромышленного комплекса за период 2010-2016 гг., р.

\begin{tabular}{|c|c|c|c|c|c|c|c|}
\hline Показатель & 2010 & 2011 & 2012 & 2013 & 2014 & 2015 & 2016 \\
\hline $\begin{array}{l}\text { В лесопромышленном комплексе, } \\
\text { всего чел. }\end{array}$ & 41212 & 37269 & 38504 & 35835 & 33214 & 31777 & 34585 \\
\hline \% к предыдущему году & - & 92,6 & 103,3 & 93,1 & 92,7 & 95,7 & 108,8 \\
\hline $\begin{array}{l}\text { В том числе } \\
\text { Обработка древесины и производ- } \\
\text { ство изделий из дерева }\end{array}$ & 13485 & 13301 & 13665 & 13919 & 12876 & 11772 & 12684 \\
\hline \% к предыдущему году & - & 100,1 & 102,7 & 101,9 & 92,5 & 91,4 & 107,7 \\
\hline $\begin{array}{l}\text { Производство целлюлозы, } \\
\text { древесной массы, бумаги, картона } \\
\text { и изделий из них }\end{array}$ & 6572 & 6758 & 6737 & 6049 & 4749 & 4798 & 5273 \\
\hline \% к предыдущему году & - & 102,9 & 99,7 & 89,8 & 78,5 & 101,0 & 109,9 \\
\hline Производство мебели & 2043 & 1805 & 1912 & 1994 & 1788 & 1856 & 2003 \\
\hline \% к предыдущему году & - & 88,4 & 105,9 & 104,3 & 89,7 & 103,8 & 107,9 \\
\hline Лесозаготовки & 19112 & 15405 & 16190 & 13873 & 13801 & 13351 & 14625 \\
\hline \% к предыдущему году & - & 75,6 & 105,1 & 85,7 & 99,5 & 96,7 & 109,5 \\
\hline $\begin{array}{l}\text { Всего в обрабатывающих производ- } \\
\text { ствах, чел. }\end{array}$ & 114232 & 113585 & 112340 & 109193 & 103827 & 103637 & 103292 \\
\hline
\end{tabular}


Производительность труда (выработка) в 2016 г. по сравнению с 2010 г. на деревообрабатывающих производствах выросла в 3 раза, в целлюлозно-бумажном производстве - в 2,5 раза, в производстве мебели в 2,2 раза, в лесозаготовках - в 2,3 раза. Самая высокая производительность труда в целлюлозно-бумажном производстве 10,91 млн р. в год на одного работника.

Основной тенденцией изменения кадрового потенциала в отрасли является значительный рост производительности труда за исследуемый период, а главное, темпы роста производительности труда работающих опережают темпы роста средней заработной платы, т. е. эфффективность использования трудовых ресурсов повышается. Это происходит за счет роста технического уровня производства.

Стоит отметить сохранение в 2016 г. тенденции к увеличению показателей производства изделий из дерева и обработки древесины (табл. 2):

- за 1-й квартал 2016 г. предприятиями данной сферы деятельности отгружено продукции на общую сумму 11 428,0 млн р., что составляет 121,3 \% к аналогичному периоду прошлого года;

- за два месяца 2016 г. прибыль предприятий данного вида экономической деятельности составила 756,2 млн р., что на 25,9 \% выше аналогичного периода прошлого года.

Рост прибыли объясняется реализацией на территории области предприятиями отрасли семи приоритетных инвестиционных проектов, направленных на создание лесопильно-деревообрабатывающих предприятий на территории региона, а также на эфффективное освоение лесного комплекса (ЗАО «ЛДК Игирма», ООО «Транс-Сибирская лесная компания», ООО «Русфорест Магистральный», ООО «Евразия леспромгрупп», ООО «ЛП Ангара», ООО «Компания «Госстрой»). В результате модернизации существующих предприятий наметились позитивные изменения в структуре использования заготовленной древесины. В табл. 3 представлен перечень инвестиционных проектов, их цели и сроки реализации, объем инвестиций.

В первом квартале 2017 г. завершены два из семи реализуемых на территории Иркутской области приоритетных инвестиционных проектов в области освоения лесов: ООО «Русфорест Магистральный» (приказ Минпромторга России от 30 января 2017 г. № 219) и ОАО «Группа «Илим» (приказ Минпромторга России от 16 марта 2017 г. № 745). Таким образом, продолжается реализация пяти приоритетных инвестпроектов в области освоения лесов ${ }^{5}$. Кроме того, предприятие ООО «Сибирские топливные гранулы» реализует проект строительства заводов древесных топливных гранул (пеллет) в Иркутской области, которым предусмотрено строительство двух заводов мощностью 115 тыс. т в год в п. Новая Игирма и 75 тыс. т в год в г. Усть-Куте с перспективой развития до 280 тыс. т в год готовой продукции. Готовая продукция будет поставляться на рынки Китая, Европы, Японии, Южной Кореи.

${ }^{5}$ URL: http://irkobl.ru/sites/alh/UpravlenieLesProm/ InvestPolPriorProektov $/$ PIP $/$ ?type $=$ special.

Таблица 2

Финансовые результаты деятельности предприятий лесопромышленного комплекса

\begin{tabular}{|l|r|r|r|r|r|r|r|}
\hline \multicolumn{1}{|c|}{ Показатель } & \multicolumn{1}{|c|}{2010} & \multicolumn{1}{|c|}{2011} & \multicolumn{1}{c|}{2012} & \multicolumn{1}{c|}{2013} & \multicolumn{1}{c|}{2014} & \multicolumn{1}{c|}{$2016^{*}$} \\
\hline $\begin{array}{l}\text { Финансовый результат деятельно- } \\
\text { сти предприятий (сальдо), млн р. }\end{array}$ & 3195,5 & 4489,7 & $-2033,6$ & $-6273,8$ & $-939,0$ & $-4560,1$ & \\
\hline $\begin{array}{l}\text { Обработка древесины и производ- } \\
\text { ство изделий из дерева }\end{array}$ & $-1076,3$ & $-853,5$ & $-459,8$ & $-638,2$ & 403,0 & 843,6 & 4100,9 \\
\hline $\begin{array}{l}\text { Производство целлюлозы, } \\
\text { древесной массы, бумаги, картона } \\
\text { и изделий из них }\end{array}$ & 5624,0 & 6554,1 & $-1119,6$ & $-3790,3$ & 2997,0 & $-574,8$ & 7,0 \\
\hline Лесозаготовки & $-1352,2$ & $-1210,9$ & $-454,2$ & $-1845,3$ & $-4339,0$ & $-4828,9$ & $\ldots$ \\
\hline Прибыль, млн р. & 7958,4 & 7660,7 & 1857,4 & 1847,8 & 5815,0 & 2419,5 & \\
\hline $\begin{array}{l}\text { Обработка древесины и производ- } \\
\text { ство изделий из дерева }\end{array}$ & 477,6 & 464,9 & 664,1 & 767,6 & 1625,0 & 2074,8 & 4305,0 \\
\hline $\begin{array}{l}\text { Производство целлюлозы, } \\
\text { древесной массы, бумаги, картона } \\
\text { и изделий из них }\end{array}$ & 7167,3 & 6977,1 & 1091,9 & 1007,2 & 4031,0 & 10,8 & 11,1 \\
\hline Лесозаготовки & 313,5 & 218,7 & 101,4 & 73,0 & 159,0 & 333,9 & $\ldots$ \\
\hline
\end{tabular}

Без учета ОАО «Группа «Илим». 
Перечень инвестиционных проектов

Таблица 3

\begin{tabular}{|c|c|c|c|c|}
\hline \multirow[b]{2}{*}{ Проект } & \multirow{2}{*}{$\begin{array}{c}\text { Срок } \\
\text { реализа- } \\
\text { ции, годы }\end{array}$} & \multirow[b]{2}{*}{ Цель проекта } & \multicolumn{2}{|c|}{$\begin{array}{c}\text { Объем инвестиций, } \\
\text { млн р. }\end{array}$} \\
\hline & & & План & $\begin{array}{c}\text { Факт } \\
\text { на } 1 \text { января } \\
2017 \text { г. }\end{array}$ \\
\hline $\begin{array}{l}\text { ЗАО «ЛДК «Игирма». } \\
\text { «Строительство лесопиль- } \\
\text { но-деревообрабатываю- } \\
\text { щего комплекса в поселке } \\
\text { Новая Игирма Нижнеилим- } \\
\text { ского района Иркутской } \\
\text { области мощностью } 434 \\
\text { тыс. м пиломатериалов } \\
\text { в год» }\end{array}$ & $2008-2014$ & $\begin{array}{l}\text { Освоение принципиально нового уровня } \\
\text { технологий в лесопереработке; достиже- } \\
\text { ние наивысшего качества выпускаемой } \\
\text { продукции; вовлечение в переработку } \\
\text { дополнительно } 1 \text { млн м³ круглых лесоматери- } \\
\text { алов; безотходность производства; развитие } \\
\text { производств, использующих технологии глу- } \\
\text { бокой переработки древесины; повышение } \\
\text { производительности труда до лидирующего } \\
\text { отраслевого уровня }\end{array}$ & 3016,00 & 6051,00 \\
\hline $\begin{array}{l}\text { ООО «Транс-Сибирская } \\
\text { лесная компания». } \\
\text { «Создание лесопильно- } \\
\text { деревообрабатывающего } \\
\text { комплекса в г. Усть-Кут» }\end{array}$ & 2014-2018 & $\begin{array}{l}\text { Создание и модернизация объектов } \\
\text { комплексной переработки древесины, } \\
\text { объектов лесной и лесоперерабатывающей } \\
\text { инфраструктуры (лесных дорог, лесоза- } \\
\text { готовительной и лесовозной техники) на } \\
\text { территории муниципального образования } \\
\text { г. Усть-Кут, Усть-Кутского и Киренского } \\
\text { районов Иркутской области }\end{array}$ & 7029,00 & 7109,00 \\
\hline $\begin{array}{l}\text { ООО «Русфорест } \\
\text { Магистральный». «Стро- } \\
\text { ительство лесоперера- } \\
\text { батывающего комбината } \\
\text { по производству сухих } \\
\text { пиломатериалов» }\end{array}$ & $2015-2018$ & $\begin{array}{l}\text { Создание производственных мощностей } \\
\text { по глубокой переработке древесины в пгт } \\
\text { Магистральный Казачинско-Ленского района } \\
\text { Иркутской области }\end{array}$ & 1344,60 & 1479,00 \\
\hline $\begin{array}{l}\text { ООО «Евразия-леспром } \\
\text { групп». «Создание } \\
\text { лесоперерабатываю- } \\
\text { щего комплекса в пгт } \\
\text { Магистральный на основе } \\
\text { ресурсов Казачинско- } \\
\text { Ленского и Киренского } \\
\text { районов Иркутской } \\
\text { области» }\end{array}$ & 2014-2018 & $\begin{array}{l}\text { Создание современного лесоперераба- } \\
\text { тывающего комплекса - предприятия, } \\
\text { способного к выпуску конкурентоспособ- } \\
\text { ной продукции с высокой добавленной } \\
\text { стоимостью при минимальном воздействии } \\
\text { на окружающую среду }\end{array}$ & 2050,00 & 2297,30 \\
\hline $\begin{array}{l}\text { ООО «ЛП «Ангара». } \\
\text { «Организация произ- } \\
\text { водства по глубокой } \\
\text { переработке древесины } \\
\text { с выпуском сухих } \\
\text { пиломатериалов, мебель- } \\
\text { ного щита и погонажных } \\
\text { изделий» }\end{array}$ & 2010-2015 & $\begin{array}{l}\text { Создание и модернизация объектов } \\
\text { комплексной, безотходной переработки } \\
\text { древесины, объектов лесной и лесоперера- } \\
\text { батывающей инфраструктуры }\end{array}$ & 402,20 & 461,40 \\
\hline $\begin{array}{l}\text { ООО «Компания } \\
\text { «Госстрой». «Организация } \\
\text { производства по глубокой } \\
\text { переработке древесины } \\
\text { в Иркутском районе и } \\
\text { Иркутской области» }\end{array}$ & 2014-2019 & $\begin{array}{l}\text { Организация производства по глубокой } \\
\text { переработке древесины }\end{array}$ & 328,12 & 126,00 \\
\hline $\begin{array}{l}\text { ОАО «Группа «Илим». } \\
\text { «Инвестиционный проект в } \\
\text { области освоения лесов по } \\
\text { Иркутской области } \\
\text { и Красноярскому краю» }\end{array}$ & $2008-2014$ & $\begin{array}{l}\text { Обеспечение наибольшего развития } \\
\text { лесопромышленного комплекса и создание } \\
\text { условий для превращения лесопромышлен- } \\
\text { ной деятельности в привлекательную отрасль } \\
\text { путем внедрения новых и модернизации } \\
\text { существующих технологических объек- } \\
\text { тов лесной и лесоперерабатывающей } \\
\text { инфраструктуры при освоении лесов в этих } \\
\text { регионах группой предприятий ОАО «Группа } \\
\text { «Иим» }\end{array}$ & 18700,00 & 36562,00 \\
\hline
\end{tabular}


В целях усиления механизмов привлечения инвестиций в лесопромышленный комплекс необходимо:

- структурировать лесопромышленный комплекс в направлении создания коопераций в области переработки древесины, в том числе древесных отходов;

- обеспечить прозрачность показателей деятельности структур всех организационно-правовых форм в различных областях лесного комплекса;

- применять схемы привлечения инвестиций от выпуска корпоративных ценных бумаг.

В целях оптимизации налогов необходима целесообразность применения системы включения инвестиций в уставный капитал хозяйствующего субъекта для привлечения инвестиций в строительство новых предприятий в области лесной промышленности [3].

Для привлечения инвестиций на успешно работающие предприятия, которые зарекомендовали себя как добропорядочные и благонадежные на рынках лесобумажной продукции, необходимо решить вопросы по совершенствованию на уровне государства кредитно-финансовой политики, обеспечивающей наиболее благоприятные условия вложения средств в долговременные капиталоемкие проекты в области переработки древесины, в том числе древесных отходов [6].

Налоговые поступления в бюджет региона от предприятий ЛПК в 2016 г. составили 4,8 млрд р., что превысило уровень 2010 г. на $62,3 \%$. Налоговая отдача с 1 м $3^{3}$ заготовленной древесины в 2016 г. составила 135,1 р., что превышает уровень налоговой отдачи в 2010 г. на 5,9%. Уровень объема налоговых отчислений в консолидированный бюджет Иркутской области от деятельности лесопромышленных предприятий в период с 2010 по 2016 г. представлен на рис. $7^{6}$.

Развитие лесопромышленного комплекса области сопровождается возрастанием спроса не на обезличенные объемы, а на конкретные сортименты древесины. Эффрективность производства во многом определяется тем, насколько соответствует тот или иной сортимент требованиям технологии производства того или иного вида продукции или изделия [7; 8]. Для выпуска высококачественной продукции механической переработки имеют большое значение прямоствольность, плотность, количество и размеры сучков и т. п.

В зависимости от выбранной технологии производства целлюлозы и другой продук-

6 URL: https://www.nalog.ru/rn38/related_activities / statistics_and_analytics.

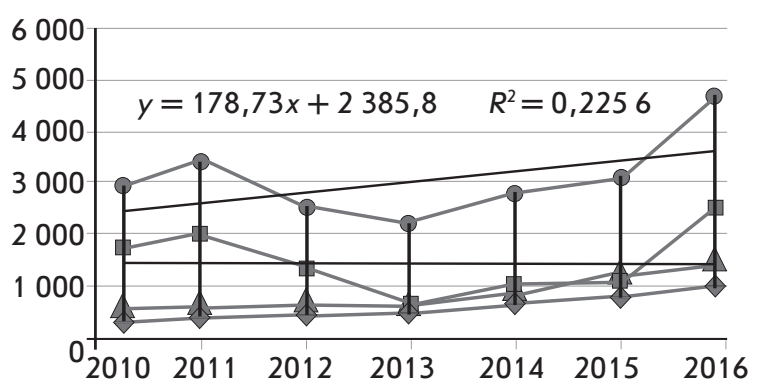

- Всего налоговых поступлений в бюджет Иркутской области

-- Производство целлюлозы, древесной массы, бумаги, картона и изделий из них

- Лесозаготовки

- Обработка древесины и производство изделий из дерева

Рис. 7. Объем налоговых отчислений в консолидированный бюджет Иркутской области от деятельности лесопромышленных предприятий в 2010-2016 гг., млн р.

ции химической переработки, а также от требований потребителей возможны существенные колебания в структуре породного состава и качества древесины [9].

Этап развития лесопромышленного комплекса области характеризуется, с одной стороны, ростом потребности в освоении лесных территорий, расположенных в ранее не обжитых регионах, в прокладке круглогодичных транспортных магистралей [10; 11]. С другой стороны, наблюдается перемещение обрабатывающих производств, требующих использования высококвалифицированного труда, в индустриальные центры (Иркутск, Братск, Усть-Илимск), которые располагают ими, а кроме того, имеют развитую производственную и социальную инфрраструктуры.

Проанализировав тенденции развития лесопромышленного комплекса Иркутской области, сделаем вывод о том, что к перспективам развития лесопромышленного комплекса можно отнести:

- существенный сырьевой запас леса с преимуществом хвойной породы - ценной древесины;

- увеличение расчетной лесосеки с целью перспективного развития лесобумажной промышленности;

- огромный водный потенциал как источник энергии;

- возможность значительного увеличения объемов производства на действующих предприятиях различного профиля за счет их модернизации, технического перевооружения, реконструкции, а также создания новых производств; 
- положительные прогнозные показатели перспективного развития рынков реализации лесобумажной продукции;

- развитие профильного обучения (лесного, лесопаркового) в образовательных учреждениях с целью выпуска высококвалифицированных специалистов в области лесных отношений.

Целенаправленность в развитии лесной промышленности заключается в увеличении объемов заготовки и комплексности использования лесных ресурсов [12].

В основе этого заложены следующие принципы:

- рациональное и комплексное использование лесных ресурсов;

- усовершенствование оборудования и утилизация устаревшего;

- максимальная загрузка имеющихся производственных мощностей, способных выпускать продукцию, пользующуюся спросом на внутреннем и внешнем рынке;
- увеличение коэфффициента глубокой переработки древесины с включением в оборот переработки мягколиственных и низкосортных пород деревьев;

- малоотходное и безотходное производство в переработке древесины;

- совершенствование структуры экспорта за счет сокращения объемов круглого леса и роста экспорта продукции с высокой добавленной стоимостью;

- развитие деревянного домостроения в рамках национальных программ;

- развитие инфраструктуры, в частности дорожной сети на землях лесного фонда;

- реализация инвестиционных проектов с целью предоставления новых рабочих мест в рамках программ социальной политики в сфере лесной промышленности, в частности переработки отходов древесины;

- охрана и защита окружающей среды, рациональность лесопользования, приумножение состава лесонасаждений ценных пород и т. д.

\section{СПИСОК ИСПОЛЬЗОВАННОЙ ЛИТЕРАТУРЫ}

1. Петров А. П. Экономика лесной промышленности : учебник / А. П. Петров, Ф. Н. Морозов. - М. : Лес. пром-сть, 1984. - 344 с.

2. Самаруха В. И. Лесопромышленный комплекс Байкальского региона: современное состояние и перспективы развития / В. И. Самаруха, Д. А. Иванова / / Сибирская финансовая школа. — 2017. — № 1 (120). C. 47-57.

3. Бирюкова А. И. Оценка инвестиционной привлекательности региона / А. И. Бирюкова // Проблемные аспекты развития транспортной системы : материалы науч.-практ. конф. с междунар. участием, Иркутск, 18 июня 2015 г. / под ред. Г.В.Давыдовой, Г. Н. Войниковой, А. И. Бирюковой. - Иркутск : Изд-во БГУЭП, 2015. - С. 33-38.

4. Давыдова Г. В. Инвестиционная привлекательность лесопромышленного комплекса Иркутской области / Г. В. Давыдова, А. И. Бирюкова / / Направления развития лесного хозяйства и лесопромышленного комплекса Иркутской области : материалы науч.-практ. конф., Иркутск, 28 окт. 2004 г. / под ред. В. П. Гукова. - Иркутск : Изд-во БГУЭП, 2005. - С. 8-17.

5. Иванова Д. А. Влияние фринансового регулирования на импортозамещение в лесопромышленном комплексе России / Д. А. Иванова / / Сибирская финансовая школа. - 2015. - № 1 (114). - С. $73-77$.

6. Глазьев С. Ю. О стратегии устойчивого развития экономики России / С. Ю. Глазьев, Г. Г. Фетисов // Экономические и социальные перемены: фракты, тенденции, прогноз. - 2013. - № 1 (25). - С. 23-35.

7. Проблемы развития лесного комплекса в регионе : сб. науч. тр. / под ред. А. И. Бирюковой. - Иркутск : Изд-во БГУЭП, 2012. - 99 с.

8. Иванова Д. А. Специфические особенности функционирования лесозаготовительной промышленности Байкальского региона [Электронный ресурс] / Д. А. Иванова / / Baikal Research Journal. — 2016. — T. 7, № 6. DOI: $10.17150 / 2411-6262.2016 .7(6)$.

9. Суходолов А. П. Целлюлозно-бумажная промышленность Байкальского региона / А. П. Суходолов. Новосибирск : Изд-во Ин-та экономики и орг. пром. пр-ва СО РАН, 1995. - 146 с.

10. Винокуров М. А. Экономика Иркутской области : в 6 т. / М. А. Винокуров, А. П. Суходолов. - Иркутск : Изд-во БГУЭП, 2009. - Т. 6. - 292 с.

11. Богомолова Е. Ю. Влияние плотности лесных дорог на объем и качество лесопромышленных и лесохозяйственных работ / Е. Ю. Богомолова, Г.В.Давыдова / / Известия Иркутской государственной экономической академии. - 2016. - Т. 26, № 2. - С. 284-290. — DOI: 10.17150/1993-3541.2016.26(2).284-290.

12. Журавлев Ю. В. Основные направления обеспечения эффективного развития промышленных предприятий и условия их выбора / Ю. В. Журавлев, Д. Ю. Матузов / / Вестник Воронежского государственного университета инженерных технологий. - 2016. - № 1 (67). - С. 288-292.

\section{REFERENCES}

1. Petrov A. P., Morozov F. N. Ekonomika lesnoi promyshlennosti [Forest Industry Economics]. Moscow, Lesnaya promyshlennost' Publ., 1984. 344 p.

2. Samarukha V. I., Ivanova D. A. The timber industry complex of the Baikal region: current status and development prospects. Sibirskaya finansovaya shkola = Siberian Financial school, 2017, no. 1 (120), pp. 47-57. (In Russian). 
3. Biryukova A. I. Assessing the Investment Potential of the Region. In Davydova G. V., Voinikova G. N., Biryukova A. I. (eds.). Problemnye aspekty razvitiya transportnoi sistemy. Materialy nauchno-prakticheskoi konferentsii, Irkutsk, 18 iyunya $2015 \mathrm{~g}$. [Challenges of the Transportation System Development. Proceedings of the Research-to-Practice Conference with International Participation, Irkutsk, June 18, 2015]. Irkutsk, Baikal State University of Economics and Law Publ., 2015, pp. 33-38. (In Russian).

4. Davydova G. V., Biryukova A. I. Investment Potential of the Timber Processing Industry of Irkutsk Oblast. In Gukov V. P. (ed.). Napravleniya razvitiya lesnogo khozyaistva i lesopromyshlennogo kompleksa Irkutskoi oblasti. Materialy nauchno-prakticheskoi konferentsii, Irkutsk, 28 oktyabrya $2004 \mathrm{~g}$. [Development Trends of Forestry and Timber Industry Complex of Irkutsk Oblast. Proceedings of the Research Conference, Irkutsk, October 28, 2004]. Irkutsk, Baikal State University of Economics and Law Publ., 2005, pp. 8-17. (In Russian).

5. Ivanova D. A. The impact of financial regulation on import substitution in the timber industry complex of Russia. Sibirskaya finansovaya shkola = Siberian Financial school, 2015, no. 1 (114), pp. 73-77. (In Russian).

6. Glazev S. Yu., Fetisov G. G. On the strategy of sustainable development of Russia's economy. Ekonomicheskie i sotsial'nye peremeny: fakty, tendentsii, prognoz = Economic and social changes: facts, trends, forecast, 2013, no. 1 (25), pp. 23-35. (In Russian).

7. Biryukova A. I. (ed.). Problemy razvitiya lesnogo kompleksa v regione [Problems of the Timber Complex Development in the Region]. Irkutsk, Baikal State University of Economics and Law Publ., 2012. 99 p.

8. Ivanova D. A. Specific features of the functioning of the logging industry in the Baikal region. Baikal Research Journal, 2016, vol. 7, no. 6. DOI: 10.17150/2411-6262.2016.7(6).7. (In Russian).

9. Sukhodolov A. P. Tsellyulozno-bumazhnaya promyshlennost' Baikal'skogo regiona [Pulp and Paper Industry of the Baikal Region]. Novosibirsk, 1995. 146 p.

10. Vinokurov M. A., Sukhodolov A. P. Ekonomika Irkutskoi oblasti [Economy of the Irkutsk Region]. Irkutsk, Baikal State University of Economics and Law Publ., 2009, vol. 6. 292 p.

11. Bogomolova E. Yu., Davydova G. V. Influence of the forest roads density on the amount and quality of the forestry work. Izvestiya Irkutskoi gosudarstvennoi ekonomicheskoi akademii = Bulletin of Irkutsk State Economics Academy, 2016, vol. 26, no. 2, pp. 284-290. DOI: 10.17150/1993-3541.2016.26(2).284-290. (In Russian).

12. Zhuravlev Yu. V., Matuzov D. Yu. Main directions of providing of industrial enterprises effective development and conditions of their choice. Vestnik Voronezhskogo gosudarstvennogo universiteta inzhenernykh tekhnologii = The Voronezh State University of Engineering Technologies, 2016, no. 1 (67), pp. 28-292. (In Russian).

\section{Информация об авторе}

Костылева Светлана Владимировна - аспирант, кафедра экономики и управления бизнесом, Байкальский государственный университет, 664003, г. Иркутск, ул. Ленина, 11, e-mail: svet2674@mail.ru.

\section{Для цитирования}

Костылева С. В. Тенденции развития лесопромышленного комплекса Иркутской области / С. В. Костылева // Известия Байкальского государственного университета. - 2018. - Т. 28 , № 2. - C. 266-274. - DOI: $10.17150 / 2500-$ 2759.2018.28(2).266-274.

\section{Author}

Svetlana V. Kostyleva - Ph.D. Student, Department of Economics and Business Management, Baikal State University, 11 Lenin St., 664003, Irkutsk, the Russian Federation, e-mail: svet2674@mail.ru.

\section{For citation}

Kostyleva S. V. Trends in the Development of the Timber Processing Complex of Irkutsk Oblast. Izvestiya Baykal' skogo gosudarstvennogo universiteta $=$ Bulletin of Baikal State University, 2018, vol. 22, no. 2, pp. 266274. DOI: $10.17150 / 2500-2759.2018 .28(2) .266-274$. (In Russian). 